\title{
Pesticide Contamination of Fish Ponds in Relation To Crop Area in a Mixed Farmland-Pond Landscape (Dombes Area - France)
}

\author{
Benoit Sarrazin ( $\sim$ bsarrazin@isara.fr) \\ ISARA-Lyon \\ Alexander Wezel \\ ISARA-Lyon \\ Mathieu Guerin \\ ISARA-Lyon \\ Joel Robin \\ ISARA-Lyon
}

\section{Research Article}

Keywords: aquaculture, fish pond, water contamination, water catchment, shallow lake, pesticides

Posted Date: January 25th, 2022

DOI: https://doi.org/10.21203/rs.3.rs-1138723/v1

License: () (1) This work is licensed under a Creative Commons Attribution 4.0 International License. Read Full License 


\section{Abstract}

Pesticides are still widely used by agriculture, leading to the exposure of surface water. This may be the case for fish ponds located in farmland landscapes. To address this issue, the present study investigated the contamination by pesticides of fish ponds located in the mixed agriculture-pond landscape of the Dombes area, France. 10 ponds were selected in water catchments with a gradient of 3-57 ha of cropland with maize and winter cereals as the dominant crops. 197 water samples were collected in the ponds during the fish production season over three years. Recently used pesticides were the most frequent residues occurring. Occurrences greater than $0.1 \mu \mathrm{g} / \mathrm{I}$ particularly concerned Chlorotoluron and S-Metolachlor. Maximum observed concentrations were slightly above $3 \mu \mathrm{g} / \mathrm{l}$ for S-Metolachlor, Acetochlor and Dimethenamide, all herbicides allowed for maize cultivation. Isoproturon and Chlorotoluron, herbicides allowed in cereal crops, reached up to 1.2 and $1.0 \mu \mathrm{g} / \mathrm{l}$, respectively. We found a significant positive effect of crop area in catchments on the ponds contamination frequency by pesticides and more significantly on the contamination frequency by broad spectrum herbicides (glyphosate and AMPA residues). The cumulative antecedent rainfall was best correlated to the frequency of highest contaminations $(>0,5 \mu \mathrm{g} / \mathrm{l})$. In such a hydrological context, crop area within catchment was identified as a good indicator of fish ponds exposure to pesticides residues. Finally, we proposed to adapt some mitigation measures to reduce fish ponds contamination.

\section{Introduction}

Fish ponds are small man-made waterbodies exploited for freshwater aquaculture. They are numerous and important in Europe or beyond and they support biodiversity and numerous others ecosystem services (Cereghino et al. 2008; Fu et al. 2018). Ponds can largely contribute to regional biodiversity as compare to river habitats (Williams et al. 2007). Agricultural landscapes containing ponds contribute to freshwater biodiversity. Consequently, protection of farm ponds from threats such as pollution is essential to maintain aquatic biodiversity (Cereghino et al. 2007). In many cases fish farming is a traditional livestock system implemented in shallow ponds. This is often an extensive system with a low input level in order to stimulate ecological drivers of food web for fish production.

Pesticides are widely used in agriculture to protect crops against pests and diseases as well as to limit competition with weeds. Pesticides are found in the environment and also human exposure to pesticides tends to become permanent today (Kim et al. 2017, De Souza et al. 2020). Pesticide use remains stable since 2008 in France (Hossard et al. 2017), despite programs and policies to reduce them. During the last decades farming systems evolved in many mixed farming areas as pond landscapes. Surfaces under livestock systems were reduced because of unfavorable economic context, whereas areas under cropping increased. Such changes in land use have contributed to locally increase pesticide uses (Urruty et al. 2016).

Pesticides pollution remains today a major threat for aquatic ecosystems (De Souza et al, 2020). In the case of ponds, herbicides can affect plankton communities and through this the entire ecosystem (Mohr et al. 2008). Pesticide transfer and drift from cropland to surface water is a well-known process as non-point source pollution. It depends on many hydrological and chemical processes. At the field scale, annual herbicide loads are mainly due to overland flow (Louchart et al. 2001) or surface runoff (Lefrancq et al. 2017). Moreover, fast transfer can occur in ditches draining adjacent fields towards surface waters (Louchart et al. 2001). In most studies, pesticide fluxes increase with increasing water discharge. Application date of pesticides before rainfall events (Boithias et al. 2014) and rainfall patterns (Meite et al. 2018) are also crucial factors influencing pesticide transfer to surface waters. However, many studies indicated that a major part of pesticides leaving the fields were degraded or adsorbed on soil particles or organic matters during the transfer (Louchart et al. 2001). Therefore, such diffuse transfer processes bring generally a limited proportion of pesticides to the aquatic systems as compare to the total quantity applied in agricultural catchments (Poissan et al. 2008).

Few studies reported multi-year exposure to pesticides of ponds or shallow lakes. Some studies investigated small water bodies located adjacent to agricultural fields (Du Preez et al. 2005; Ulrich et al. 2018). They show that pesticide concentrations found in the water bodies were correlated with rainfall amount during application periods, land use of the sites, physicochemical parameters of active ingredients and the applied amount of pesticides. A field study in the Camargue Rhône river delta, France, showed that runoff from rice fields carried important loads of dissolved pesticides to the wetlands in the area (Cormoretto et al. 2008).

In fish ponds of Northeastern France which are directly connected to small streams, Lazartigues et al. (2013) showed that many pesticides were found in the water due to a strong connection between ponds and streams, but with concentrations varying between

Page 2/19 
sites and seasons. In general, a strong connection between ponds and watersheds highlight a high vulnerability of fish ponds but also surface water bodies for contamination of pesticides (Cereghino et al. 2008).

The aim of the study was to characterize fish ponds' exposure to pesticide residues during the fish production period. For this purpose, fish pond' water catchments were delineated included water drainage ditches, type and surface of crops located, crop rotations investigated as well as the agricultural use of pesticides. In addition, pesticides residues were measured in the fish pond water at several sampling dates over three years. Our hypothesis was that the higher the crop area in catchment, the higher is the frequency of contamination by pesticides. We also expected that the highest pesticide residues contaminations occurred for the most mobile pesticides active ingredients and with significant rainfall-runoff periods. An operational perspective was to design management recommendations for farmers in order to reduce the frequency and quantity of contamination of the pond aquatic ecosystem.

\section{Materials And Methods}

\subsection{Study area}

The studied fish pond landscape, the Dombes area, is located in eastern France, and includes around 1100 ponds (Fig. 1). The fish production system in the ponds includes a particular traditional practice which is rare in Europe: extensive fish farming and grain farming alternate on the same unit of land. Ponds are emptied every year in autumn or winter for fish harvesting, and then refilled for another annual fish growth season. After 3-4 years, the ponds are emptied and left to dry up to be cultivated mainly with oats, maize or sorghum for 1 year (Wezel et al. 2013). The water that fills the ponds during the wet phase comes either from a pond situated at a higher elevation or from a network of ditches which collect runoff from the catchment. In such cases land use can affect water parameters such as nutrients in fish ponds (Wezel et al. 2013). Cropping systems and fish ponds systems are closely linked in related to water management in the Dombes area. Crop farmers often create gullies on the soil surface after sowing to drain surface water out from the fields since the prevailing clayey-loamy soils are very sensitive to water excess and runoff. On the other side, fish farmers maintain a network of ditches to collect water in a catchment to fill fish ponds in winter and spring. In this context, the vulnerability of surface water to the transfer of pesticides is an important question for fish farmers. It is essential to better understand the risk of contamination of fish ponds by pesticides residues.

\subsection{Fish pond selection}

We have selected 10 fish ponds in the study area among a list of 30 available ponds from fish producers involved in a regional research program aiming to improve fish ponds productivity based on available natural resources. These are typical ponds for fish production, having a relevant cropland in the pond catchment. We eliminated ponds that get their water resources mostly from emptying upstream ponds. Pond catchments boundaries were precisely delineated from topographic maps and aerial images in a Geographical Information System (GIS). The catchment maps were corrected by field surveys and validated with fish farmers who explained the water pathways and ditches they use to collect water and fill the ponds after fish harvest (Fig. 1). Land use was distinguished for cropland (including the various crops), vegetation (woodland or permanent grassland) and artificial areas (buildings and roads).

\subsection{Identification of crop rotations and selection of pesticides active ingredients}

Interviews were conducted with a sample of five farmers who crop in the catchments of the studied ponds. The surveys concerned crop rotations leading to multiyear variation in pesticide applications, field water management with below-ground and/or surface drainage, and pesticide uses. Winter cereals and maize were found to be the key cash crops included in crop rotations with other less frequent crops like rapeseed, sunflower, soybean or temporary grasslands. Other interviews were carry out with prescribers of plant protection products to get an overview of plant protection products used in the study area. The interviews allowed establishing a list of potential active ingredients of pesticides to be found in the water samples of fish ponds. A particular attention was given to active ingredients with low soil adsorption coefficients, meaning that they are highly mobile in soils. Koc indicator values as organic carbonwater partition coefficient, were obtained on the French national institute for industrial environment and risks website (https://substances.ineris.fr). This is an important parameter to assess the ability of an active ingredient to be transferred out of fields by runoff processes (Poissant et al. 2008). However, pesticides with higher soil adsorption values were kept in the list because

Page 3/19 
they can be transported by surface runoff with soil organic particles. Finally, a list of more than three hundred active ingredients was established to be analyzed with the water samples.

\subsection{Assessing fish ponds contamination regarding crop area and rainfall}

We wanted to investigate the correlation between crop area and ponds contamination to assess pond exposure to pesticides residues during the fish growing season. Crop rotations can induce strong variations in pesticides uses in a particular pond catchment over the three years of monitoring. Moreover, it was essential to distinguish rainfall effects especially on the highest contaminations. Hence the crop rotations and rainfall effects were studied to compare ponds exposure to pesticides. The European Union fixed the maximum admissible concentrations of pesticide residues in drinking water at $0.1 \mu \mathrm{g} / \mathrm{l}$ for a single substance and 0.5 $\mu \mathrm{g} / \mathrm{l}$ for the sum of pesticide residues. This is a widely used water quality standard system in the European Union. We used these threshold values as indicators to distinguish between low or high contamination levels in ponds water samples.

\subsubsection{Water sampling}

We collected 197 water samples over three years in 10 ponds, with six to seven samples per ponds and per year. Samples were collected during the fish growing season from February to October. Spring and early summer is the period when most pesticide applications occur. Seven ponds were sampled during three years. Three ponds could be only sampled two years because they were completely drained and cultivated during one year with cereals. During the sampling period we collected water samples with a Van Dorn water sampler. We mixed three similar sub-samples to generate a sample and then stored in dark at $4^{\circ} \mathrm{C}$ before analysis. The 10 ponds were all sampled during the same half day.

For each year we sampled first at the end of winter to check ponds' water quality at the beginning of the fish growing season. At this time, fish ponds may not be systematically full of water. Then, the next samples were regularly collected during spring and summer, if possible after significant rainfall events. A rain gauge located in the center of the study area was used as a reference for rainfall monitoring (Meteo-France rain gauge station of Marlieux). To control occurrence of significant surface runoff, we followed the weather forecasts and the cumulated rainfall during five days before determining the sampling dates in spring.

In the water samples potential three hundred active ingredients were analyzed both in the dissolved and particulate phases. The laboratory of water analyses was accredited by the French authorities for determination of pesticide concentration. The quantification thresholds for the analyzed active ingredients ranged from 10 to $100 \mathrm{ng} / \mathrm{l}$. An occurrence of contamination was recorded when the concentration of an active ingredient exceeded its quantification threshold value in a water sample. Occurrences of each single substance concentration higher than $0.1 \mu \mathrm{g} / \mathrm{l}$ were also indicated.

The frequency of contamination indicates the number of occurrences of a repeating contamination per unit of time. It is the number of occurrences divided by the number of available water samples during a period. The frequency ranges up to $100 \%$ when all water samples of a targeted period are contaminated by pesticides. Occurrences of contamination greater than $0.5 \mu \mathrm{g} / \mathrm{l}$ for the sum of pesticide residues were also included in order to calculate the frequency of highest contaminations. The frequency of contamination was the main outcome variable to assess ponds exposure to pesticides.

\subsubsection{Influence of rainfall, crop area and crop type on fish ponds contamination}

Cumulative rainfall for 2, 5, 10 and 20 days before each water sampling date were compared to the frequency of contamination calculated for each sampling date over the 10 studied ponds, first from all contamination occurrence, and secondly for those greater than $0.5 \mu \mathrm{g} / \mathrm{l}$ for the sum of pesticide residues. A correlation analyses was carried out to highlight significant dependence between cumulative rainfall and pond contamination over the three years monitoring thanks to the Spearman's rank correlation coefficient.

Crop area within each pond's catchment was extracted from the GIS database. These values were compared to the frequency of contamination calculated for each pond over the three years monitoring, firstly from all contamination occurrences and secondly for those with a concentration higher than $0.5 \mu \mathrm{g} / \mathrm{l}$ for the sum of pesticide residues. A linear regression model using the least squares approach was used to assess the strength of the relationship between pond contamination frequency and crop area in their catchment. The Shapiro-Wilk Normality test was carried out to check the normality of the variables introduced in the linear regression models. 
To determine the source of pesticides found in ponds we focused on the three most important pesticide uses in crop fields around fish ponds: broad spectrum herbicides, winter cereal pesticides and maize pesticides. Broad spectrum herbicides (principally glyphosate) are used by farmers before crop planting in order to control weeds, hence its use does not depend on a particular crop. With a similar approach as total pesticides contaminations, we compared total crop area within pond's catchments to broad spectrum herbicides frequency of contamination over the three years. Annual maize and winter cereal areas were also extracted from the GIS database for each pond's catchment and compared to annual frequency of contamination of pesticides permitted for use in these crops. For this, Spearman's rank correlation coefficient was used. Correlations were calculated for the three years monitoring and for each year separately to investigate interannual changes induced by difference in crop rotations.

\section{Results}

\subsection{Pesticide occurrence and maximum concentrations in fish ponds}

Pond and catchment areas ranged respectively from 2 to 14 ha and from 6 to 98 ha (Table 1). The cropped area in pond's catchments ranged from 2 to 57 ha. Hence, catchments composition of the ten selected fish ponds constituted a gradient of exposure to pesticide transfer (Fig. 2). Half of catchments were strongly dominated by cropland, however, in few catchments woodland or permanent grassland was quite important.

Table 1

Fish ponds areas, catchment areas, number of water samples collected and dry year over the three years of pesticides monitoring.

\begin{tabular}{|lllll|}
\hline Fish pond & $\begin{array}{l}\text { Pond area } \\
\text { (ha) }\end{array}$ & $\begin{array}{l}\text { Total catchment area } \\
\text { (ha) }\end{array}$ & Number of water samples & Dry year during 2013 to 2015 \\
\hline A & 3 & 19 & 22 & - \\
\hline B & 14 & 60 & 14 & 2014 \\
\hline C & 3 & 22 & 22 & - \\
\hline D & 7 & 27 & 22 & - \\
\hline E & 14 & 41 & 15 & 2015 \\
\hline F & 12 & 31 & 22 & - \\
\hline G & 12 & 92 & 22 & - \\
\hline H & 11 & 42 & 22 & - \\
\hline I & 6 & 6 & 22 & 2014 \\
\hline J & 8 & 98 & 14 & - \\
\hline
\end{tabular}

In the 10 fish ponds, 20 active ingredients were found in the water samples (Table 2). This included 16 herbicides of which one a glyphosate metabolite (AMPA), three fungicides and one insecticide. Their use is most frequent for winter cereals (9) followed by use for maize (4) and as broad spectrum herbicides (3). AMPA which is the first metabolite of glyphosate used for broad spectrum weeding had the highest occurrence. It is followed by several herbicides used in maize (S-metolachlore, Dicamba) or winter cereals (Chlortoluron, Isoproturon). Imidacloprid was the only quantified insecticide with an occurrence of 20 times which was the fifth occurrence rank. It is used for seeds treatments before sowing. 
Table 2

Active ingredients found in 10 fish ponds in the Dombes area (southeastern France) over three years monitoring. Type of pesticide: $\mathrm{H}$ : Herbicides, I: Insecticides, F: Fungicides, M: Metabolite); Authorized French use(s): BS: Broad Spectrum, Div: diverse uses, WC: winter cereals uses, M: maize use, R: rapeseed use; Koc is the organic carbon-water partition co-efficient (values from INERIS

https://substances.ineris.fr). Total number of samples is 197 with 6 to 7 samples per pond and per year. The occurrence is the number of samples in which an ingredient has exceeded the threshold value of quantification. AMPA is aminomethylphosphonic acid, a metabolite of glyphosate.

\begin{tabular}{|c|c|c|c|c|c|c|c|c|}
\hline $\begin{array}{l}\text { Active } \\
\text { ingredient }\end{array}$ & $\begin{array}{l}\text { Pesticide } \\
\text { type }\end{array}$ & $\begin{array}{l}\text { Crop } \\
\text { use }\end{array}$ & Occurrences & $\begin{array}{l}\text { Occurrences } \\
>0.1 \mu \mathrm{g} / \mathrm{l}\end{array}$ & $\begin{array}{l}\text { Maximum } \\
\text { concentration } \\
(\mu \mathrm{g} / \mathrm{l})\end{array}$ & $\begin{array}{l}\text { Koc } \\
\text { range } \\
(\mathrm{L} / \mathrm{Kg})\end{array}$ & $\begin{array}{l}\text { Limit of } \\
\text { quantification } \\
\text { (ng/l) }\end{array}$ & $\begin{array}{l}\text { Contaminated } \\
\text { ponds }(\%)\end{array}$ \\
\hline AMPA & M & BS & 75 & 9 & 0.139 & $\begin{array}{l}1160- \\
24800\end{array}$ & 20 & 80 \\
\hline Chlorotoluron & $\mathrm{H}$ & WC & 72 & 36 & 0.952 & $\begin{array}{l}108- \\
384\end{array}$ & 20 & 60 \\
\hline S-Metolachlor & $\mathrm{H}$ & $M$ & 46 & 19 & 3.400 & $\begin{array}{l}110- \\
488\end{array}$ & 35 & 80 \\
\hline Isoproturon & $\mathrm{H}$ & WC & 29 & 6 & 1.240 & 139 & 20 & 60 \\
\hline Imidacloprid & 1 & WC & 20 & 2 & 0.219 & $\begin{array}{l}109- \\
411\end{array}$ & 20 & 60 \\
\hline Dicamba & $\mathrm{H}$ & M & 18 & 2 & 0.134 & $2-5$ & 60 & 80 \\
\hline Flurtamone & $\mathrm{H}$ & WC & 9 & 5 & 0.101 & 329 & 20 & 20 \\
\hline Boscalid & $\mathrm{F}$ & WC & 8 & 3 & 0.122 & $\begin{array}{l}507- \\
1110\end{array}$ & 20 & 20 \\
\hline Glyphosate & $\mathrm{H}$ & BS & 8 & 0 & 0.080 & $\begin{array}{l}884- \\
60000\end{array}$ & 20 & 30 \\
\hline Prosulfocarb & $\mathrm{F}$ & WC & 7 & 0 & 0.068 & $\begin{array}{l}1367- \\
2339\end{array}$ & 20 & 50 \\
\hline Acetochlor & $\mathrm{H}$ & $M$ & 7 & 3 & 3.400 & $\begin{array}{l}28- \\
377\end{array}$ & 20 & 20 \\
\hline Dimethenamid & $\mathrm{H}$ & $M$ & 7 & 5 & 3.300 & $\begin{array}{l}40- \\
233\end{array}$ & 40 & 20 \\
\hline Fluroxypyr & $\mathrm{H}$ & WC & 5 & 0 & 0.092 & $\begin{array}{l}50- \\
136\end{array}$ & 20 & 20 \\
\hline Clopyralid & $\mathrm{H}$ & Div & 5 & 1 & 0.124 & $5-6$ & 100 & 20 \\
\hline 2.4.MCPA & $\mathrm{H}$ & WC & 4 & 0 & 0.079 & $\begin{array}{l}10- \\
157\end{array}$ & 20 & 10 \\
\hline Linuron & $\mathrm{H}$ & Div & 3 & 0 & 0.100 & $\begin{array}{l}555- \\
987\end{array}$ & 20 & 10 \\
\hline 2.4.D & $\mathrm{H}$ & BS & 2 & 0 & 0.093 & $5-212$ & 30 & 10 \\
\hline Metazachlor & $\mathrm{H}$ & $\mathrm{R}$ & 2 & 0 & 0.057 & $\begin{array}{l}75- \\
110\end{array}$ & 25 & 20 \\
\hline Aminotriazole & $\mathrm{H}$ & BS & 1 & 0 & 0.070 & $\begin{array}{l}20- \\
202\end{array}$ & 50 & 10 \\
\hline Fluoxastrobine & $\mathrm{F}$ & WC & 1 & 0 & 0.071 & 1003 & 50 & 10 \\
\hline
\end{tabular}

The six ingredients most often found were detected in 18 to 75 samples and in 60 to $80 \%$ of the ponds. The occurrence of all other substances did not exceed 9 samples and were found in less than $30 \%$ of ponds except Prosulfocarb (5 ponds) and Glyphosate ( 3 ponds) but the concentrations were closed to the limit of quantification. 
Occurrences greater than $0.1 \mathrm{\mu g} / \mathrm{I}$ particularly concerned herbicides as Chlorotoluron and S-Metolachlor with 36 and 19 occurrences, respectively. They are soil-applied pre-emergent herbicides used in winter cereals and maize to control germinating weeds. In most cases, occurrences greater than $0.1 \mu \mathrm{g} / \mathrm{l}$ are related to herbicides active ingredients having Koc values lower than $500 \mathrm{l} / \mathrm{kg}$.

Maximum observed concentrations over $3 \mu \mathrm{g} / \mathrm{l}$ was for S-Metolachlor, Acetochlor and Dimethenamide all herbicides allowed for maize. This is followed by the winter cereal herbicides Isoproturon and Chlorotoluron that reached 1.24 and $0.95 \mu \mathrm{g} / \mathrm{l}$, respectively. The other substances remained below $0.2 \mu \mathrm{g} / \mathrm{l}$ except Imidacloprid with $0.219 \mu \mathrm{g} / \mathrm{l}$.

\subsection{Contaminations correlated to rainfall and crop area}

Total rainfall from February to September in the 3 study years was $691 \mathrm{~mm}$ in 2013, $549 \mathrm{~mm}$ in 2014 and 430 in 2015 . This variability of rainfall induced a variability of cumulative rainfall before sampling dates especially in 2013 (Fig. 3). Ponds C and I showed very low contaminations (Fig. 4), and ponds A, E, F and G had intermediate levels. Ponds B, H, J and D were affected by at least one high contamination value, greater than $1 \mu \mathrm{g} / \mathrm{l}$ in 2013. Spring 2013 was characterized by high and frequent rainfall that particularly correlated with increased pesticides contamination frequencies: cumulative rainfall amounts over 20 days prior to sampling exceeded $100 \mathrm{~mm}$ on two occasions (Fig. 3). The next two years of monitoring were less rainy and consequently the contamination frequencies decreased, especially the high contaminations. The frequency of contamination differentiated by pesticide types followed this trend (Fig. 5): for broad spectrum herbicides it was only low contamination. For winter cereals pesticides, the frequency decreases over the years but high frequency value or high contaminations remained at the end of winter. For maize pesticides the frequency reached a peak in spring and tended to decrease during spring except in 2013 and for one date in 2014.

In all cases cumulative rainfall was positively correlated to contamination frequencies in the monitored fish ponds ranging from 0.3 to 0.5 (Table 3). Cumulative rainfall values were more strongly correlated to the high contamination frequency $(>0.5 \mu \mathrm{g} / \mathrm{l})$ as compared to all contaminations. The five days cumulative rainfall was best correlated to the high contamination frequency (Rho $=$ $0.53 ; p<0,01)$. Only the two days' cumulative rainfall was significantly correlated with all contaminations frequency $(\mathrm{Rho}=0.44$; $p<0,05)$.

Table 3

Spearman's rank correlation (rho) between antecedent cumulative rainfall over $2,5,10$ or 20 days and contamination frequency in the 10 monitored fish ponds over three years. Significance levels: ${ }^{*} p<0,05 ; * \star p<0,01 ; * \star * p<$ 0,$001 ;$ ns $p>0,05$.

\begin{tabular}{|llclc|}
\hline Cumulative rainfall & \multicolumn{2}{l|}{ All contaminations } & \multicolumn{2}{l|}{ Contaminations $>0.5 \mu \mathrm{g} / \mathrm{l}$} \\
\hline 2 days & 0.44 & $*$ & 0.49 & $*$ \\
\hline 5 days & 0.37 & $\mathrm{~ns}$ & 0.53 & $* *$ \\
\hline 10 days & 0.30 & $\mathrm{~ns}$ & 0.45 & $*$ \\
\hline 20 days & 0.41 & $\mathrm{~ns}$ & 0.51 & $*$ \\
\hline
\end{tabular}

The linear regression models showed a positive effect of crop area in pond catchments on the frequency of all contaminations $(p<0.05)$ and more importantly for broad spectrum herbicides contaminations $(p<0.001)$. Conversely, crop area had no significant effect ( $p>0.05$ ) on high contaminations frequency (Fig. 6).

\subsection{Contaminations from maize pesticides and from winter cereal pesticides}

The global annual distribution of crop areas in pond catchments were quite similar from 2013 to 2015 (Fig. 7), with maize and winter cereals the two major ones. The correlations between contamination frequencies and crop areas over the three years were positive (Table 4), but much more significant for maize $(p<0.001)$ than for winter cereals $(p<0.05)$. Annual contamination frequencies of maize pesticides in the fish ponds were positively correlated to maize areas planted each year in the pond catchments in 2013 $(p<0.05)$ and $2014(p<0.01)$, but not in 2015. Only annual frequency of contamination by winter cereals pesticides in 2015 was significantly correlated to winter cereals area $(p<0.05)$. 
Table 4

Spearman's rank correlation (rho) between winter cereal and maize area in pond catchments and

frequency of contamination by pesticides used in ten monitored fish ponds. Significance: * $p<0,05$; ** $p<0,01 ; * \star \star p<0,001 ; n s p>0,05$.

\begin{tabular}{|llllll|}
\hline Sampling period & \multicolumn{4}{ll}{ Winter cereal } & \multicolumn{2}{l|}{ Maize } \\
\hline Three years & 0.46 & $*$ & 0.71 & $* \star *$ \\
2013 & 0.37 & Ns & 0.68 & $*$ \\
2014 & 0.38 & Ns & 0.91 & $* \star$ \\
2015 & 0.75 & $*$ & 0.51 & ns \\
\hline
\end{tabular}

\section{Discussion}

\subsection{Fish ponds contamination in relation to crop area and pesticides uses}

We analysed contamination by pesticides in fish ponds from areas cropped mainly with winter cereals and maize along a gradient of crop area in catchments. Contamination was predominantly related to six active ingredients which were low soil adsorption herbicides, except AMPA which is the first glyphosate metabolite and Imidacloprid which is an insecticide used for seeds protection. Only $38 \%$ of water samples taken were free of pesticide residues. Our hypothesis of a correlation between cropland area and global frequency of contamination in fish ponds was confirmed (Fig. 6). The most frequent and highly concentrated active ingredients found were related to current pesticide uses in maize and winter cereals (Table 2). In previous studies surface water contaminations were also associated with current used pesticides (Du Preez et al. 2005; Ulrich et al. 2018; Cui et al. 2020). Some pesticides residues such as S-metolachlor and Dimethenamid were also found in previous studies in runoff water that supplies fish ponds with water in the same area (Sarrazin et al. 2011).

AMPA residues was found in 8 out 10 ponds and Glyphosate on 3 out 10 ponds, both sometime with high concentrations (Table 2), and its frequency of contamination was strongly related to crop area in pond catchments (Fig. 6). Glyphosate is sprayed by farmers before crops planting in order to clean the fields from weeds that developed during the period between two crops or to destroy winter cover crops. Its use has increased as a result of the development of reduced or no tillage farming. Glyphosate and AMPA are now very frequent in topsoils of cropped fields in Europe (Silva et al. 2018) or other farming nations like Argentina (Aparicio et al. 2013). Silva et al. (2018) indicated that cereal crops show the highest exports for Glyphosate through water erosion, but also for AMPA being more persistent than glyphosate, its mother compound.

Spraying periods for winter cereals are usually October or more frequently late February/early March with pre-emergent herbicides. Fungicides are sprayed in spring, and very few insecticides are used in the study region. We found principally Isoproturon and Chlorotoluron that are both pre-emergent herbicides. The temporal pattern of the high contamination levels is consistent with cumulative rainfall after spraying at the out of winter after (Fig. 5). Ponds are exposed to these residues especially in early spring.

The spraying periods for maize were late April/early May with pre-emergent herbicides just after sowing. The monitoring we conducted demonstrated that pesticide applications in maize is responsible for the highest quantified contamination in fish ponds from S-metolachlor, Acetochlor and Dimethenamid that are pre-emergent herbicides (Table 2). S-metolachlor was also the most frequent maize herbicide found in the ponds. This substance was regularly detected in surface waters in various countries. Following a recent review on occurrences of pesticides in surface waters for the period 2012-2019 it is the second most frequent herbicide found (De Souza et al. 2020). The dissipation rates of Metolachlor from maize fields were measured as only a few percent ( $\mathrm{Ng}$ et al. 1995; Rose et al. 2018), but the dosage of the herbicide product is relatively high. Maize was the dominating crop in the crop rotations of farmers in our case study (Fig. 7). The temporal pattern of maize pesticides contaminations was particularly well consistent with the maize chemical protection schedule which coincides with the middle of the fish production season in May/June (Fig. 5). Peak concentrations occurred in late spring, and decreased over the remaining part of the production season. Soil cover in maize fields was very low at this time as compared to winter cereals. It may have facilitated surface runoff with pesticide transfers to the ponds. Finally, strong correlations between maize crop area and related pesticides contamination frequency confirmed that 
frequent pesticide transfer can occurs from this crop toward fish ponds. It was less in 2015, probably because the rainfall was very low in spring (Table 4).

Few studies have been dedicated on non-point source pollution of fish ponds by pesticides. In a previous study in barrage ponds of northeastern France, five ponds were monitored in spring and fall (Lazartigues et al. 2012). Few active ingredients exceeded the threshold of $1 \mu \mathrm{g} / \mathrm{l}$ for a single substance but the total pesticide level in October reached 0.17 to $8.81 \mu \mathrm{g} / \mathrm{l}$ depending on the pond. Herbicides as Isoproturon and Chlorotoluron were frequently quantified, which were also among the most important ones in our study. The total contaminations of water observed in March followed the gradient of cultivation area percentages in the catchment (Lazartigues et al. 2012).

\subsection{Rain fall and connectivity as most important factors for pesticide transfer}

We found that higher rainfall events in the preceding days correlated well with higher frequency of contamination as well as higher concentrations of pesticides found in the fish ponds. Hydrological parameters are more relevant than pesticides characteristic to explain pesticide transport toward water bodies (Ulrich et al. 2018). Our fish pond landscape is dominated by loamy-clayey loess soils that are very prone to structural degradation by compaction or rainfall impact. Consequently, they are vulnerable to Hortonian runoff (Reichenberger et al. 2007). Saturation excess runoff can also occur in fields around the ponds, because of soils with impermeable horizons. And preferential flow can contribute to the transfer of pesticides when drainage systems were installed (Reichenberger et al. 2007). As pointed out by a previous study focused on nutrients status of Dombes fish ponds in relation to cropland area in pond catchments (Wezel et al. 2013), our results also illustrated the impacts of the strong hydrological connectivity between crop fields and ponds. In such a relatively flat area, the drainage network is particularly well developed because artificial drains or ditches are essential part of the channel network. In such a high drainage density context, our results confirmed the ones of Collin et al (2000) showing that the total surface area of the catchment must be taken into account as contributive areas for herbicides contamination in surface water. The artificial drainage network managed by farmers and fish producers (Fig. 1) is consequently a very important way of pesticides transfers.

Several parameters can influence surface water contamination as rainfall, spraying dates, type of pesticides (Boithias et al. 2014). As found in a recent monitoring of ten small water bodies in Germany (Ulrich et al. 2018), our results on ten fish ponds were also strongly variable (Fig. 4) because of combination of rainfall temporal pattern, spraying time and type of pesticides used. Sites characteristics like slope or soil types could also locally influence the results but they are relatively homogeneous in the Dombes area which is a plateau of glacial origin. However, the dense artificial drainage network can be spatially variable in its ability to transfer pesticide residues. According to their characteristics and management practices, ditches could also be an asset in controlling the flow of pesticide residues (Lagacherie et al. 2006).

Numerous studies concluded to the importance of precipitations playing a major part in the herbicide transfer after their application (Garmouma et al. 1997) and indicate application time as more important than application rate (Holvoet et al. 2005). The time between the rain and the treatment is essential in the contamination process of surface waters (Reichenberger et al. 2007), and this is also the case for the contamination of water bodies (Ulrich et al. 2018). Our results were consistent with these findings because we found significant positive correlation between cumulated antecedent rainfall for 2 days and the contamination frequency $(p<0,05)$ but not for previous cumulated rainfall over longer periods. In contrast, the correlations were higher for the high contamination frequency with longer cumulated antecedent rainfall periods. This can be explained by the temporal pattern of the saturation of the soil with water during the spraying period in spring. Due to the high frequency of heavy rainfall in 2013 (Fig. 3), rainfall-runoff events occurred close to maize sowing and pre-emergent herbicides spraying. Conditions were drier and clearly different in 2014 and 2015. Our results also showed that contaminations can persist for several weeks after the application periods as it can be observed in streams (Garmouna et al. 1997). Overall, we must remain cautious about the interpretation of our data regarding detecting peak exposure and maximum contamination in fish ponds caused by rainfall as this would need a higher frequency sampling (Lefrancq et al. 2017).

\subsection{Impacts on fish pond aquatic ecosystem and human health}

Different studies show impacts of pesticides on different components of aquatic ecosystem. Smedbol et al. (2018) showed effects of Glyphosate in freshwater phytoplankton community, but the concentrations tested were much higher than those observed in the

Page 9/19 
Dombes fish ponds. Current herbicides such as Metolachlor can affect phytoplankton cultures and communities at environmentally relevant concentrations (Beaulieu et al. 2020). The authors pointed out the risk to the health of phytoplankton in lakes at concentrations below current national guidelines. The increasing sensitivity of some Chlorophyceae algae after being previously exposed to several pulse of Metolachlor was also demonstrated (Copin et al. 2016). Thunissen et al. (2020) assessed ecological risks of imidacloprid to aquatic species. Aquatic insects were found to be particularly sensitive. A mesocosm study revealed effect of Imidacloprid on aquatic invertebrates (Rico et al. 2018). Calculated no observed effect concentration were $0.2 \mu \mathrm{g} / \mathrm{l}$ for some taxa which is less than the maximal concentrations we observed in one of our fish ponds. We should add here that the mixture of pesticides can be more toxic than the individual active ingredient although this type of impact is currently poorly understood (De Souza et al., 2020).

Fish ponds themselves can be used as pesticides mitigation in surface waters. They can contribute to limit downstream pollution by pesticides in case of barrage fish ponds (Gaillard et al. 2016). However, fish ponds in Dombes are in most cases enclosed basins of water with a very low water turn over during the fish production season. Pond fish such as carp or pike may be intended for human consumption. Nevertheless, the risk of contaminating the fish seemed unlikely according to previous studies. Sarrazin et al. (2011) found no contamination in the flesh of the fish, but only with low concentration in the liver which is normally not consumed. Current uses pesticides were also monitored in sediments and fish of some northeastern French fishponds (Lazartigues et al. 2013a). Among other substances, Isoproturon was present in all sediments samples and in some fishes at very low levels. In the same area, another study led to the conclusion that none of the active ingredients found would probably be bioaccumulated within aquatic food webs (Lazartigues et al. 2013b).

\subsection{Operational perspectives and mitigation measures}

Using contamination frequency as outcome variable, we demonstrated the consequence of increased crop area in pond catchments on decreasing pond water quality. As the work was carried out with local stakeholder, results should support operational decision making and giving recommendations for improved management. In the hydrological context of the Dombes area, the frequency of contamination could be controlled by taking better account of the rainfall history before pesticide treatments in particular to control high contamination of pond water. Deeper changes in cropping systems such as longer and more diversified crop rotations which support having less pest or disease incidence (Wezel et al. 2014) could also help to reduce the contamination frequency of fish ponds as treatment frequency, type and amount of pesticides used could diminish. The list of the active ingredients involved in treatments could also help farmers to select herbicides with less mobility.

Numerous mitigation measures can be considered to prevent pesticide transfer from runoff such as buffer strips, hedge rows and forest buffer, constructed wetlands, tillage practice, cover crops, and intercropping. Beyond local implementation, it is necessary to look for additive effect in the larger catchment with a combination of mitigation measures on total pesticide losses (Reichenberger et al. 2007; Carluer et al. 2017). It is essential to design vegetated buffer zones adapted to the specific context of the area following water pathways and local practices (Syversen and Bechmann 2004; Carluer et al. 2017). Many ponds benefit from vegetation belts, however riparian buffer strips are probably much less effective than edge-of-field buffer strips because riparian buffer strips are known as better for drift control than for runoff control (Lacas et al. 2005). Grass strips are known to be effective but their efficiency depends on the context (Reichenberger et al. 2007). Attention must be paid on the risk of channeling of surface flow within the strip which could considerably reduce efficiency (Lacas et al. 2005). Constructed wetlands are considered as good tools to clean surface waters from pesticides residues in farmland landscapes (Tournebize et al. 2013). It is well suited to catch water from artificial drainage network in agricultural catchments (Passeport et al. 2013) and the presence of plants enhances pesticide retention (Vymazal et al. 2015). It could also be small detention ponds that are cheap and can easily be created with on-farm machinery (Fiener et al. 2005). But all these measure are just mitigation measure and are not tackling the origin of the problem which is too high or too frequent pesticide application. Some policies are in place for this (e.g. Ecophyto programme and policy in France), but new ones might have a strong impact on farmers' practices such as the EU Farm to Fork strategy which sets a target to reduce pesticide use by $50 \%$ by 2030 (European Commission 2020).

\section{Conclusions}

Our study shows that pesticides contamination frequency in fish ponds was closely related to the total crop area in catchments. In such a mixed farmland and pond landscape, fish ponds vulnerability to pesticide residues was widely variable during the fish 
production season. In the most fish ponds contamination was dominated by herbicides and their temporal pattern of application. The strong hydrological connectivity between crop fields and ponds was responsible for high contamination levels not only in higher rainfall years but also after significant rainfall events. The correspondence between maize and fish ponds production cycles was particularly implicated in the contamination process from pre-emergent herbicides used in this crop.

In view of the active ingredients quantified, expected impacts could principally concern disturbances of phytoplankton community. It seems difficult to totally prevent contamination of exposed fish ponds in such a hydrological context without deep changes in cropping systems. Reducing the frequency of contamination may be an achievable goal. From this perspective, taking better account of rainfall history and avoiding mobile active ingredients during pre-emergence treatments seem essential. In addition, vegetative buffers and constructed wetlands might be promising mitigation tools, but need to be adapted for every pond situation at risk. It requires commitment of farmers and fish producers in collaboration with scientists and stakeholders to investigate and implement such mitigation measures.

\section{Declarations}

\section{Acknowledgments}

We thank the fish farmers and crop farmers for allowing access to sampling the sites and for their participation to surveys. We thank also Thomas Lhuillery, Margaux Thirard and Guillaume Brodin for the technical assistance, as well as Laurence Garnier from the Agricultural Chamber of Ain department for the agronomic surveys with the farmers.

\section{Author contribution}

All authors contributed to the study conception and design. Material preparation, data collection and analysis were performed by Benoit Sarrazin and Mathieu Guérin. The first draft of the manuscript was written by Benoit Sarrazin and all authors commented on previous versions of the manuscript. All authors read and approved the final manuscript.

\section{Funding}

We thank the Ain department council, and the Auvergne Rhône-Alpes Regional council for financial supports.

\section{Data availability}

Not applicable.

\section{Ethics approval and consent to participate}

Not applicable.

\section{Consent for publication}

Not applicable.

\section{Competing interests}

The authors have no financial or proprietary interests in any material discussed in this article. The authors have no relevant financial or non-financial interests to disclose.

\section{References}

1. Aparicio VC, De Gerónimo E, Marino D, Primost J, Carriquiriborde P, Costa JL (2013) Environmental fate of glyphosate and aminomethylphosphonic acid in surface waters and soil of agricultural basins. Chemosphere 93(9):1866-1873. https://doi.org/10.1016/j.chemosphere.2013.06.041

2. Beaulieu M, Cabana H, Huot Y (2020) Adverse effects of atrazine DCMU and metolachlor on phytoplankton cultures and communities at environmentally relevant concentrations using Fast Repetition Rate Fluorescence. Sci Total Environ 712:136239. 
https://doi.org/10.1016/j.scitotenv.2019.136239

3. Boithias L, Sauvage S, Srinivasan R, Leccia O, Sánchez-Pérez JM (2014) Application date as a controlling factor of pesticide transfers to surface water during runoff events. CATENA 119:97-103. https://doi.org/10.1016/j.catena.2014.03.013

4. Carluer N, Lauvernet C, Noll D, Munoz-Carpena R (2017) Defining context-specific scenarios to design vegetated buffer zones that limit pesticide transfer via surface runoff. Sci Total Environ 575:701-712. https://doi.org/10.1016/j.scitotenv.2016.09.105

5. Céréghino R, Ruggiero A, Marty P, Angélibert S (2007) Biodiversity and distribution patterns of freshwater invertebrates in farm ponds of a south-western French agricultural landscape. In: Oertli B., Céréghino R., Biggs J., Declerck S., Hull A., Miracle M.R. (eds) Pond Conservation in Europe. Developments in Hydrobiology 210 Springer, Dordrecht pp 43-51 https://doi.org/10.1007/978-90-481-9088-1_5

6. Comoretto L, Arfib B, Talva R, Chauvelon P, Pichaud M, Chiron S, Höhener P (2008) Runoff of pesticides from rice fields in the lle de Camargue (Rhône river delta, France): Field study and modeling. Environ Pollut 151(3):486-493.

https://doi.org/10.1016/j.envpol.2007.04.021

7. Copin PJ, Perronet L, Chèvre N (2016) Modelling the effect of exposing algae to pulses of S-metolachlor: How to include a delay to the onset of the effect and in the recovery. Sci Total Env 541:257-267. https://doi.org/10.1016/j.scitotenv.2015.08.154

8. Cui S, Hough R, Yates K, Osprey M, Kerr C, Cooper P, Coull M, Zhang Z (2020) Effects of season and sediment-water exchange processes on the partitioning of pesticides in the catchment environment: Implications for pesticides monitoring. Sci Total Env 698:134228. https://doi.org/10.1016/j.scitotenv.2019.134228

9. De Souza RM, Seibert D, Beatriz Quesada H, De Jesus Bassetti F, Fagundes-Klen MR, Bergamasco R (2020) Occurrence, impacts and general aspects of pesticides in surface water: A review. Process Saf Environ Prot 135:22-37. https://doi.org/10.1016/j.psep.2019.12.035

10. Du Preez LH, van Jansen PJ, Jooste AM, Carr JA, Giesy JP, Gross TS, Kendall RJ, Smith EE, Van Der Kraak G, Solomon KR (2005) Seasonal exposures to triazine and other pesticides in surface waters in the western Highveld corn-production region in South Africa. Environ Poll 135(1):131-141. https://doi.org/10.1016/j.envpol.2004.09.019

11. European Commission (2020a) Farm to Fork Strategy - for a fair, healthy and environmentally-friendly food system. https://ec.europa.eu/food/farm2fork_en Accessed 23 septembre 2021

12. Fiener $P$, Auerswald $K$, Weigand $S$ (2005) Managing erosion and water quality in agricultural watersheds by small detention ponds. Agric Ecosyst Environ 110(3-4):132-142. https://doi.org/10.1016/j.agee.2005.03.012

13. Fu B, Xu P, Wang Y, Yan K, Chaudhary S (2018) Assessment of the ecosystem services provided by ponds in hilly areas. Sci Total Environ 642:979-987. v https://doi.org/10.1016/j.scitotenv.2018.06.138

14. Gaillard J, Thomas M, Luretig A, Pallez C, Feidt C, Dauchy X, Banas D (2016) Barrage fishponds: Reduction of pesticide concentration peaks and associated risk of adverse ecological effects in headwater streams. J Environ Manag 169:261-271. https://doi.org/10.1016/j.jenvman.2015.12.035

15. Garmouma M, Blanchard M, Chesterikoff A, Ansart P, Chevreuil M (1997) Seasonal transport of herbicides (triazines and phenylureas) in a small stream draining an agricultural basin: Mélarchez (France). Water Res 31(6):1489-1503. https://doi.org/10.1016/S0043-1354(96)00400-9

16. Hossard L, Guichard L, Pelosi C, Makowski D (2017) Lack of evidence for a decrease in synthetic pesticide use on the main arable crops in France. Sci Total Environ 575:152-161. https://doi.org/10.1016/j.scitotenv.2016.10.008

17. Kim KH, Kabir E, Jahan SA (2017) Exposure to pesticides and the associated human health effects. Sci Total Environ 575:525535. https://doi.org/10.1016/j.scitotenv.2016.09.009

18. Lacas J-G, Voltz M, Gouy V, Carluer N, Gril JJ (2005) Using grassed strips to limit pesticide transfer to surface water: a review. Agron Sustain Dev 25(2):253-266. https://hal.archives-ouvertes.fr/hal-00886289

19. Lagacherie P, Diot O, Domange N, Gouy V, Floure C, Kao C, Moussa R, Robbez-Masson JM, Szleper V (2006) An indicator approach for describing the spatial variability of artificial stream networks with regard to herbicide pollution in cultivated watersheds. Ecol Ind 6(2):265-279. https://doi.org/10.1016/j.ecolind.2005.02.003

20. Lazartigues A, Thomas M, Banas D, Brun-Bellut J, Cren-Olivé C, Feidt C (2013) Accumulation and half-lives of 13 pesticides in muscle tissue of freshwater fishes through food exposure. Chemosphere 91(4):530-535.

https://doi.org/10.1016/j.chemosphere.2012.12.032

Page $12 / 19$ 
21. Lazartigues A, Banas D, Feidt C, Brun-Bellut J, Thomas M (2012) Pesticide pressure and fish farming in barrage pond in Northeastern France Part I: site characterization and water quality. Environ Sci Poll Res 19(7):2802-2812. https://doi.org/10.1007/s11356-012-0784-5

22. Lazartigues A, Thomas $M$, Cren-Olivé $C$ et al (2013) Pesticide pressure and fish farming in barrage pond in Northeastern France. Part II: residues of 13 pesticides in water, sediments, edible fish and their relationships. Environ Sci Pollut Res 20:117-125. https://doi.org/10.1007/s11356-012-1167-7

23. Lefrancq M, Jadas-Hécart A, La Jeunesse I, Landry D, Payraudeau S (2017) High frequency monitoring of pesticides in runoff water to improve understanding of their transport and environmental impacts. SciTotal Environ 587-588:75-86. https://doi.org/10.1016/j.scitotenv.2017.02.022

24. Louchart X, Voltz M, Andrieux P, Moussa R (2001) Herbicide Transport to Surface Waters at Field and Watershed Scales in a Mediterranean Vineyard Area. J Environ Qual 30:982-991. https://doi.org/10.2134/jeq2001.303982x

25. Meite F, Alvarez-Zaldívar P, Crochet A, Wiegert C, Payraudeau S, Imfeld G (2018) Impact of rainfall patterns and frequency on the export of pesticides and heavy-metals from agricultural soils. Sci Total Environ 616-617:500-509. https://doi.org/10.1016/j.scitotenv.2017.10.297

26. Mohr S, Feibicke M, Berghahn R, Schmiediche R, Schmidt R (2008) Response of plankton communities in freshwater pond and stream mesocosms to the herbicide metazachlor. Environ Poll 152(3):530-542. https://doi.org/10.1016/j.envpol.2007.07.010

27. Ng HYF, Gaynor JD, Tan CS, Drury CF (1995) Dissipation and loss of atrazine and metolachlor in surface and subsurface drain water: A case study. Water Res 29(10):2309-2317. https://doi.org/10.1016/0043-1354(95)00071-R

28. Passeport E, Tournebize J, Chaumont C, Guenne A, Coquet Y (2013) Pesticide contamination interception strategy and removal efficiency in forest buffer and artificial wetland in a tile-drained agricultural watershed. Chemosphere 91(9):1289-1296. https://doi.org/10.1016/j.chemosphere.2013.02.053

29. Williams P, Whitfield M, Biggs J, Bray S, Fox G, Nicolet P, Sear D (2004) Comparative biodiversity of rivers, streams, ditches and ponds in an agricultural landscape in Southern England. Biol Conserv 115(2):329-341. https://doi.org/10.1016/S00063207(03)00153-8

30. Poissant $L$, Beauvais $C$, Lafrance P, Deblois C (2008) Pesticides in fluvial wetlands catchments under intensive agricultural activities. Sci Total Environ 404(1):182-195. https://doi.org/10.1016/j.scitotenv.2008.05.030

31. Reichenberger S, Bach M, Skitschak A, Frede HG (2007) Mitigation strategies to reduce pesticide inputs into ground-and surface water and their effectiveness; A review. Sci Total Environ 384(1-3):1-35. https://doi.org/10.1016/j.scitotenv.2007.04.046

32. Rico A, Arenas-Sánchez A, Pasqualini J, García-Astillero A, Cherta L, Nozal L, Vighi M (2018) Effects of imidacloprid and a neonicotinoid mixture on aquatic invertebrate communities under Mediterranean conditions. Aquat Toxicol 204:130-143. https://doi.org/10.1016/j.aquatox.2018.09.004

33. Rose CE, Coupe RH, Capel PD, Webb RMT (2018) Holistic assessment of occurrence and fate of metolachlor within environmental compartments of agricultural watersheds. Sci Total Environ 612:708-719. https://doi.org/10.1016/j.scitotenv.2017.08.154

34. Sarrazin B, Tocqueville A, Guerin M, Vallod D (2011) From agricultural plots to fishponds. Survey on pesticides in an aquacultureagriculture system. Technique Sciences Méthodes 12:49-58. (in French)

35. Silva V, Montanarella L, Jones A, Fernández-Ugalde O, Mol HGJ, Ritsema CJ, Geissen V (2018) Distribution of glyphosate and aminomethylphosphonic acid (AMPA) in agricultural topsoils of the European Union. Sci Total Environ 621:1352-1359. https://doi.org/10.1016/j.scitotenv.2017.10.093

36. Smedbol É, Pedrosa Gomes M, Paquet S, Labrecque M, Lepage L, Lucotte M, Juneau P (2018) Effects of low concentrations of glyphosate-based herbicide factor $540 \AA$ on an agricultural stream freshwater phytoplankton community. Chemosphere 192:133-141. https://doi.org/10.1016/j.chemosphere.2017.10.128

37. Syversen N, Bechmann M (2004) Vegetative buffer zones as pesticide filters for simulated surface runoff. Ecol Eng 22(3):175184. https://doi.org/10.1016/j.ecoleng.2004.05.002

38. Thunnissen NW, Lautz LS, Van Schaik TWG, Hendriks AJ (2020) Ecological risks of imidacloprid to aquatic species in the Netherlands: Measured and estimated concentrations compared to species sensitivity distributions. Chemosphere 254:126604. https://doi.org/10.1016/j.chemosphere.2020.126604

Page $13 / 19$ 
39. Tournebize J, Passeport E, Chaumont C, Fesneau C, Guenne A, Vincent B (2013) Pesticide de-contamination of surface waters as a wetland ecosystem service in agricultural landscapes. Ecological Engineering 56:51-59.

https://doi.org/10.1016/j.ecoleng.2012.06.001

40. Ulrich U, Hörmann G, Unger M, Pfannerstill M, Steinmann F, Fohrer N (2018) Lentic small water bodies: Variability of pesticide transport and transformation patterns. Sci Total Environ 618:26-38. https://doi.org/10.1016/j.scitotenv.2017.11.032

41. Urruty N, Deveaud T, Guyomard H, Boiffin J (2016) Impacts of agricultural land use changes on pesticide use in French agriculture. Eur J Agron 80:113-123. https://doi.org/10.1016/j.eja.2016.07.004

42. Vymazal J, Březinová T (2015) The use of constructed wetlands for removal of pesticides from agricultural runoff and drainage: A review. Environ Intern 75:11-20. https://doi.org/10.1016/j.envint.2014.10.026

43. Wezel A, Arthaud F, Dufloux C, Renoud F, Vallod D, Robin J, Sarrazin B (2013) Varied impact of land use on water and sediment parameters in fish ponds of the Dombes agro-ecosystem, France. Hydrol Sci J 58(4):854-871.

https://doi.org/10.1080/02626667.2013.780656

44. Wezel A, Robin J, Guerin M, Arthaud F, Vallod D (2013) Management effects on water quality, sediments and fish production in extensive fish ponds in the Dombes region, France. Limnologica 43(3):210-218. https://doi.org/10.1016/j.limno.2012.11.003

45. Wezel A, Casagrande M, Celette F, Vian JF, Ferrer A, Peigné J (2014) Agroecological practices for sustainable agriculture. A review. Agron Sustain Dev 34(1):1-20. https://doi.org/10.1007/s13593-013-0180-7

\section{Figures}

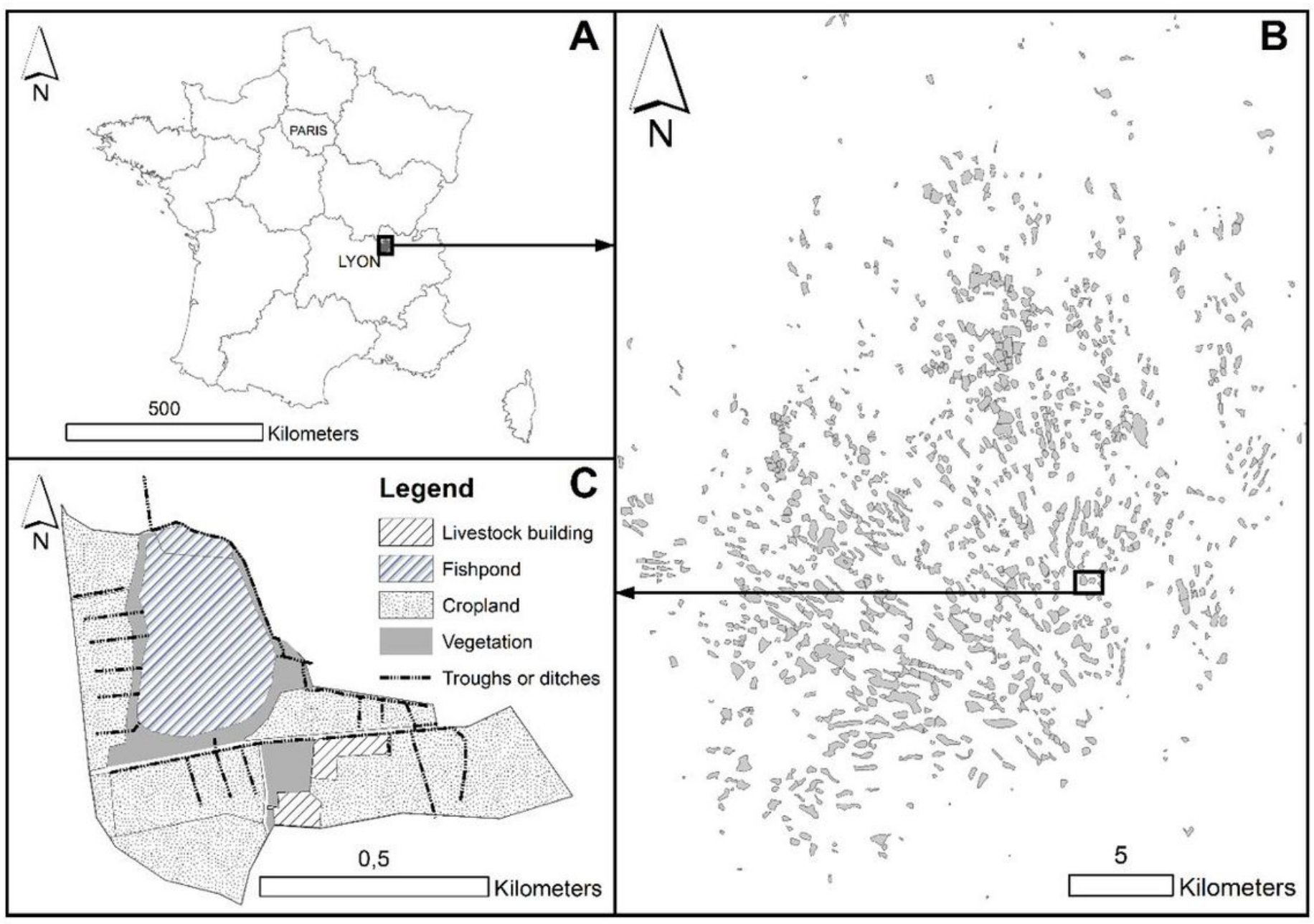

Figure 1 
Location of the Dombes region in France (A), its approximately 1,100 fish ponds (B), and a zoom on a particular fish pond and its catchment area (C). Vegetation includes shrubs, woods and wet plants.

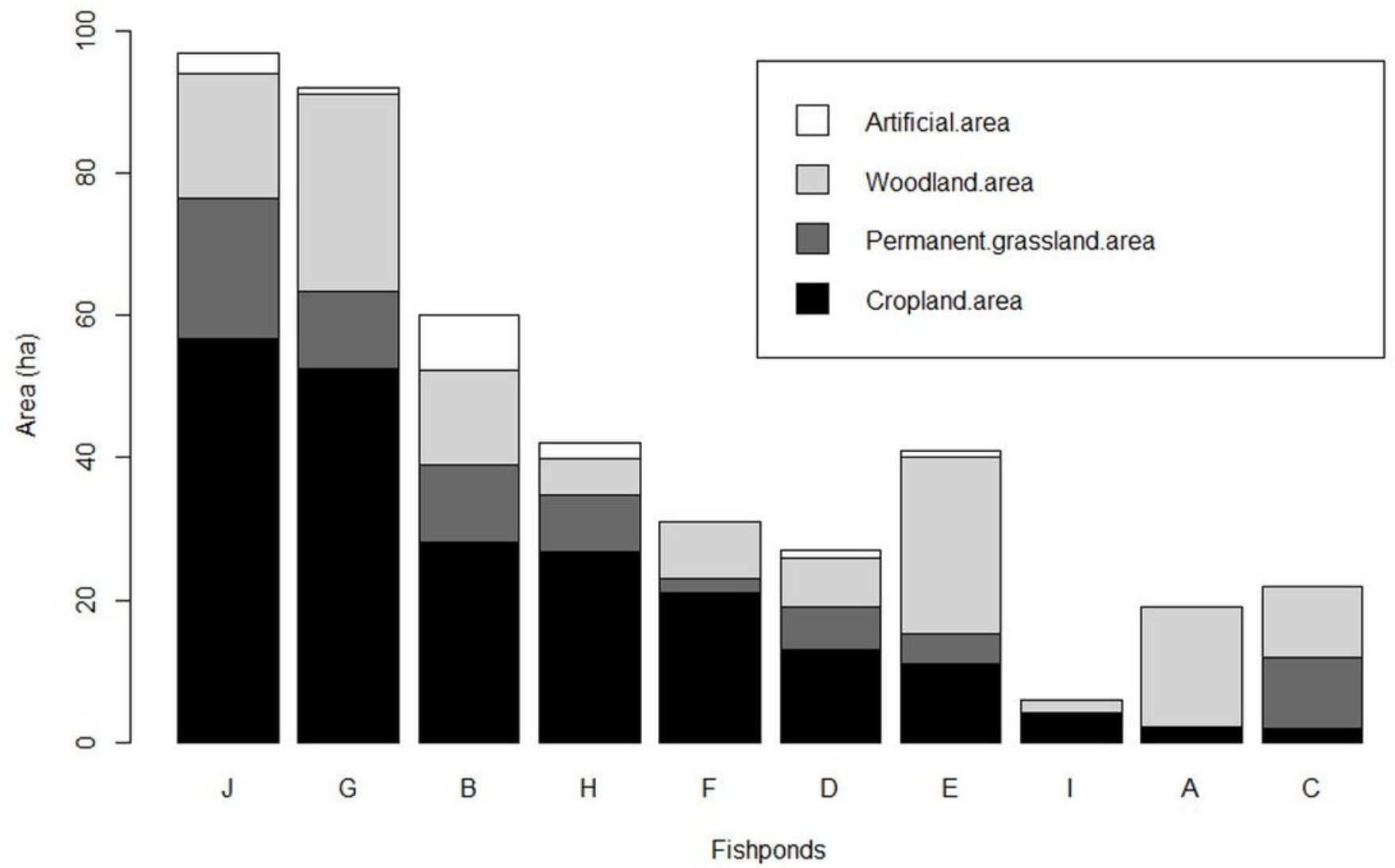

Figure 2

Land use in the watersheds of the 10 fishponds monitored for pesticide contamination, ordered by decreasing cropland area (hectares). 

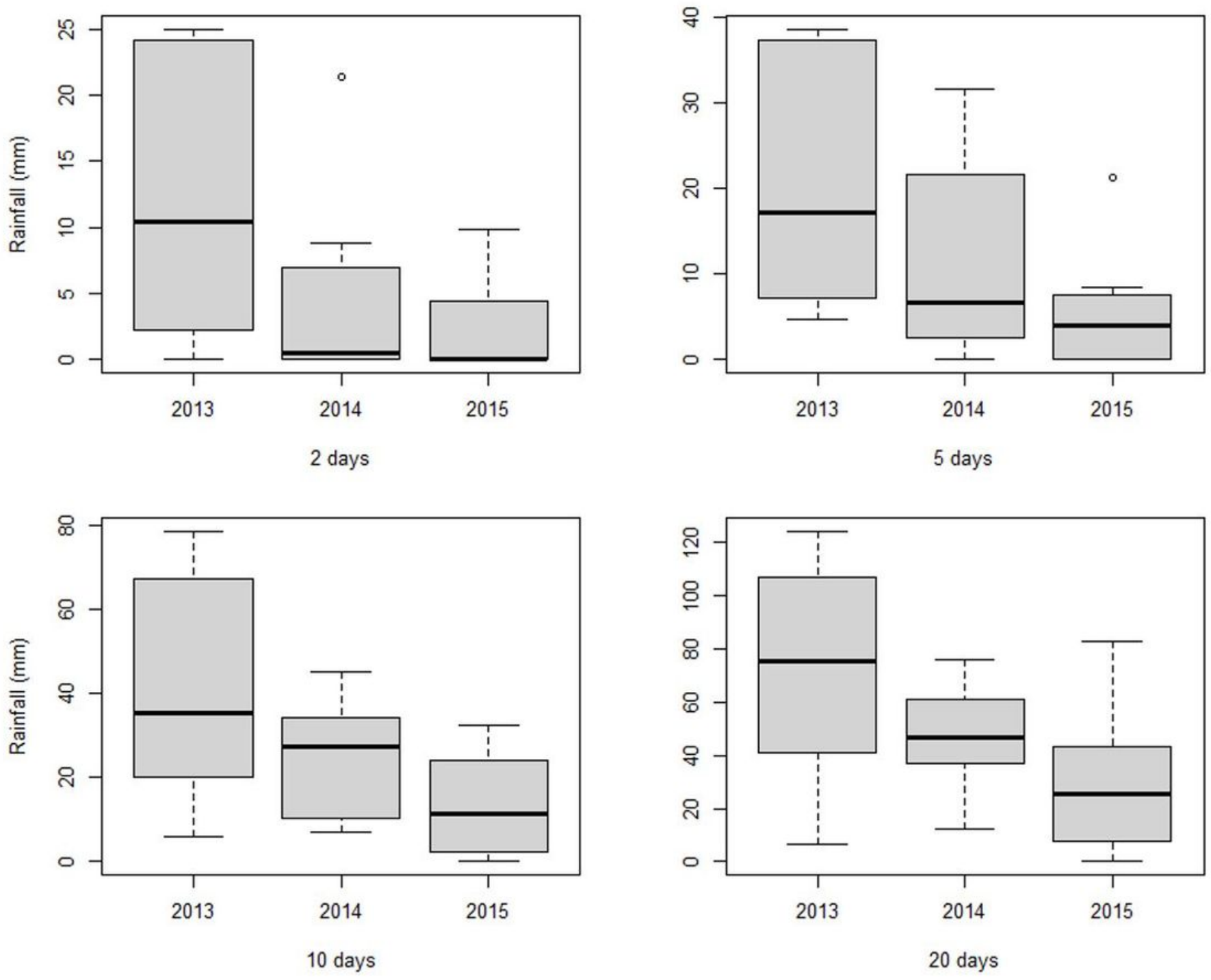

Figure 3

Annual distributions of rainfall accumulations over 2, 5, 10 and 20 days before each sampling date in the 10 monitored ponds. 

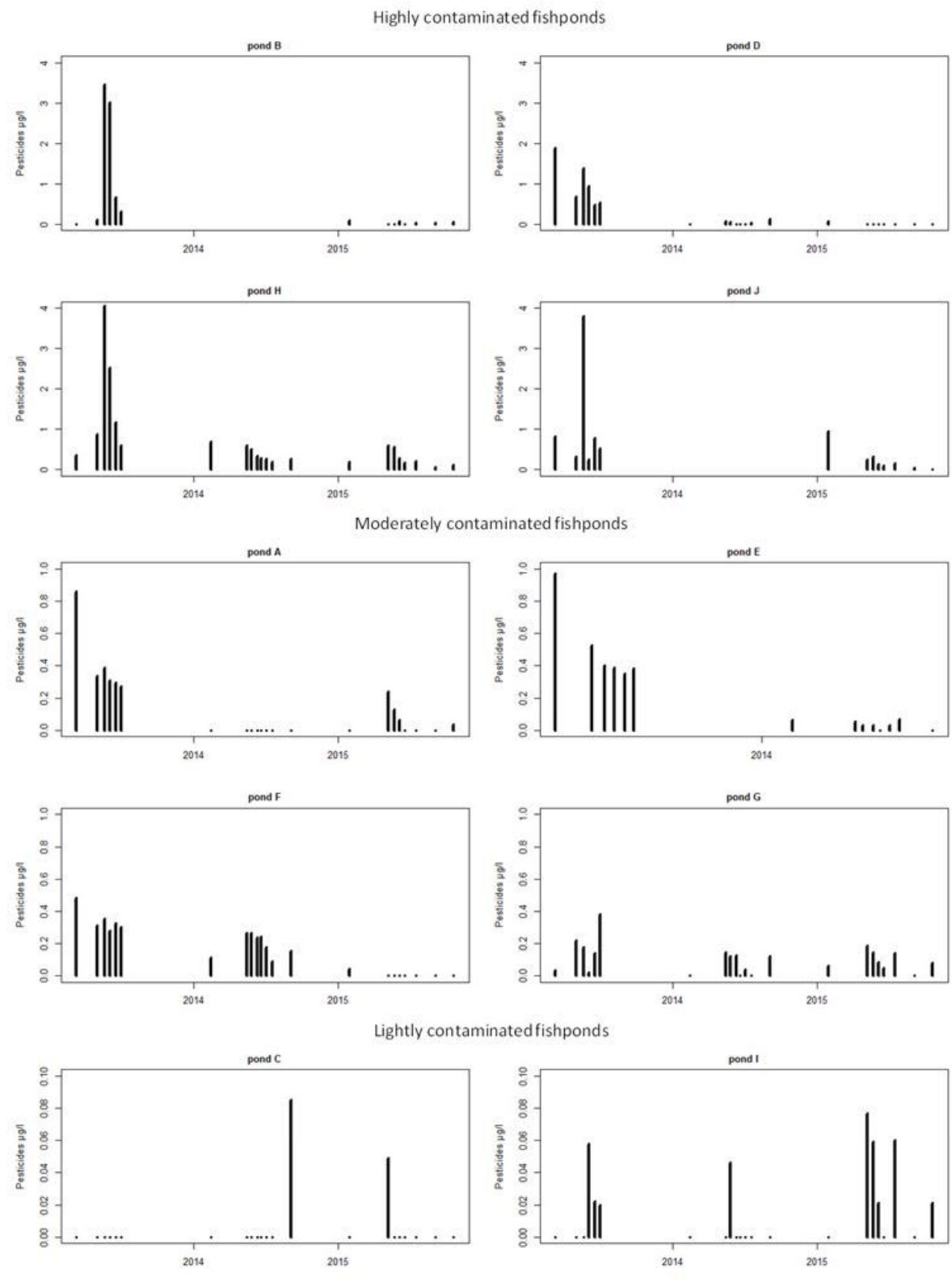

\section{Figure 4}

Total contaminations with pesticides residues in 10 monitored fish ponds (A to J) for each sample date during fish growing season over 3 years monitoring (2013 to 2015). 
Total pesticides
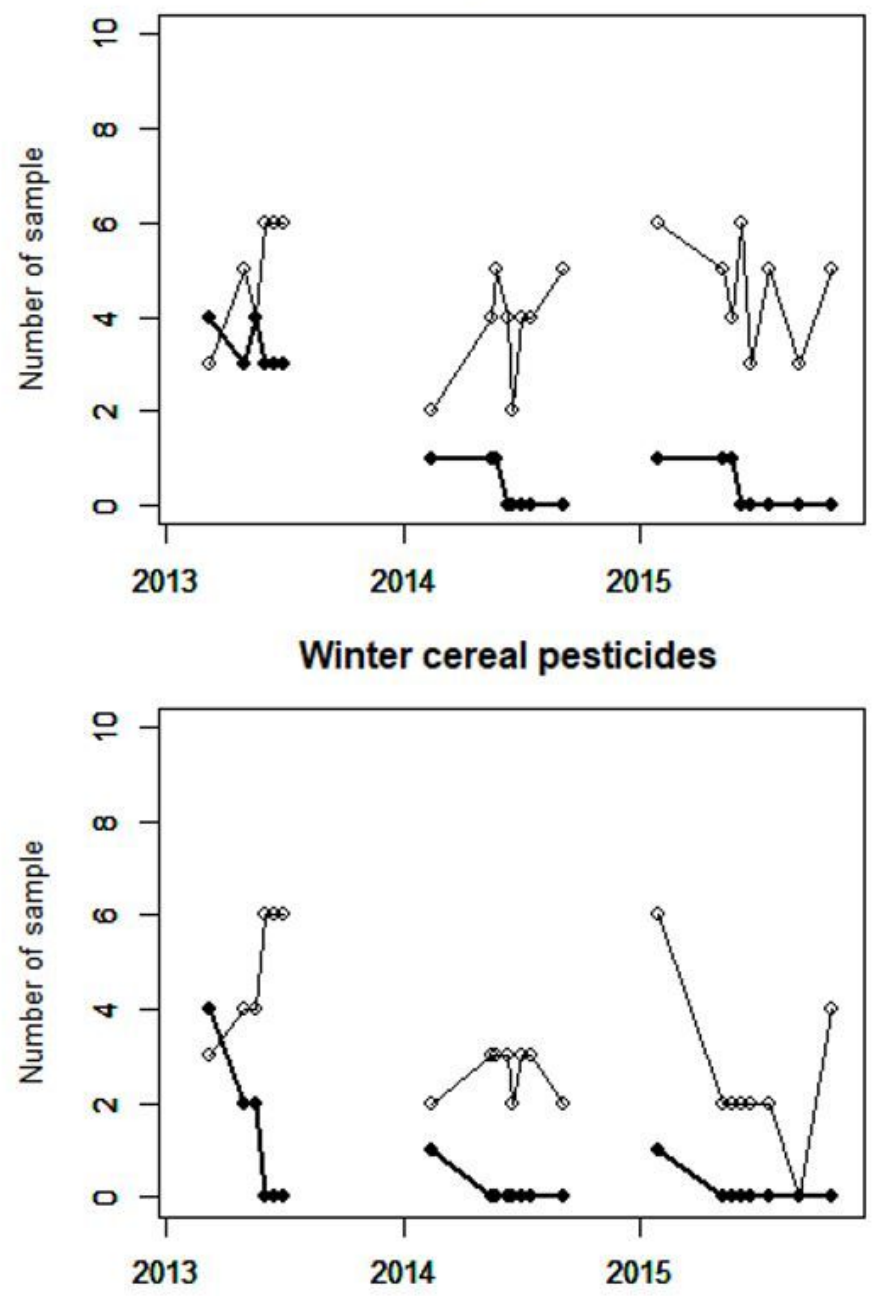

Broad spectrum herbicides
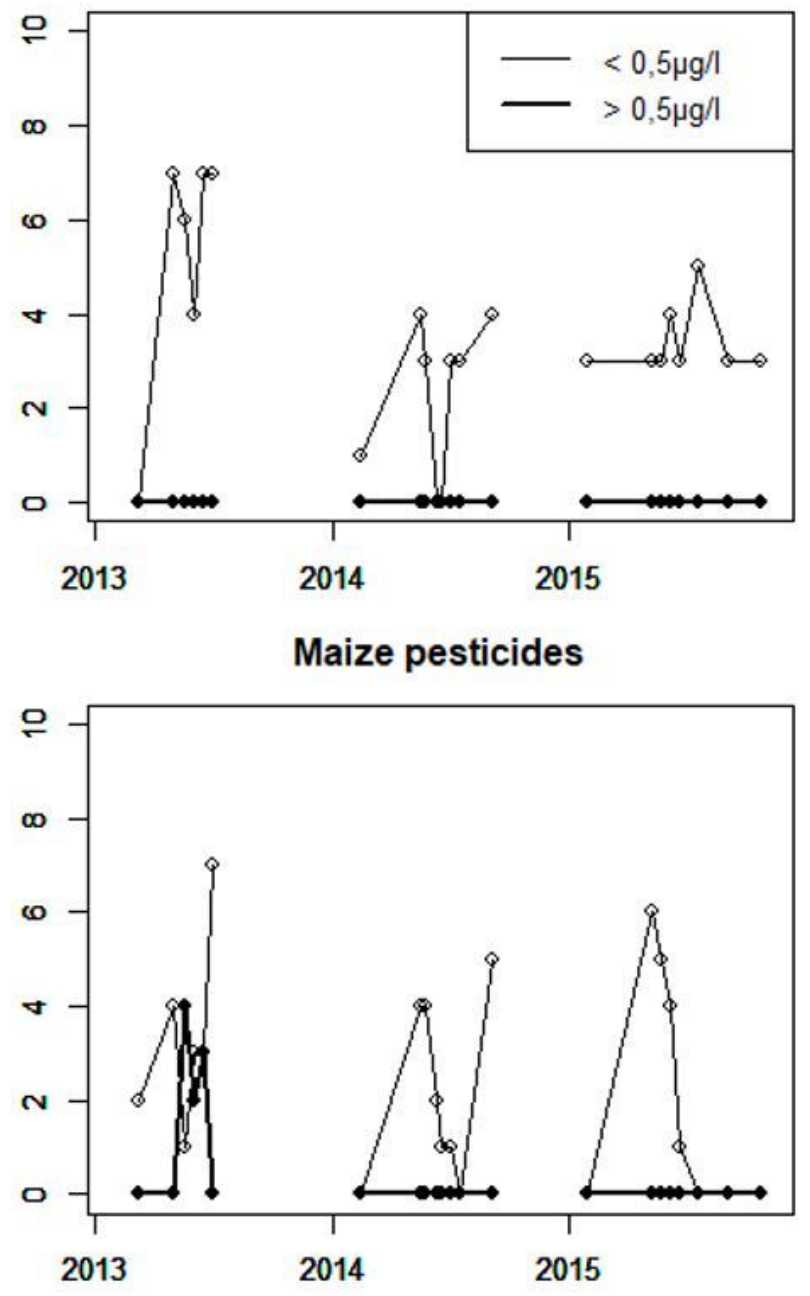

Figure 5

Number of contaminated water samples by pesticides residues lower or higher than 0,5 $\mathrm{g} / \mathrm{l}$ in 10 monitored fish ponds of Dombes area for each sample date for three years' monitoring: total pesticides, broad spectrum herbicides, winter cereals pesticides and maize pesticides. 

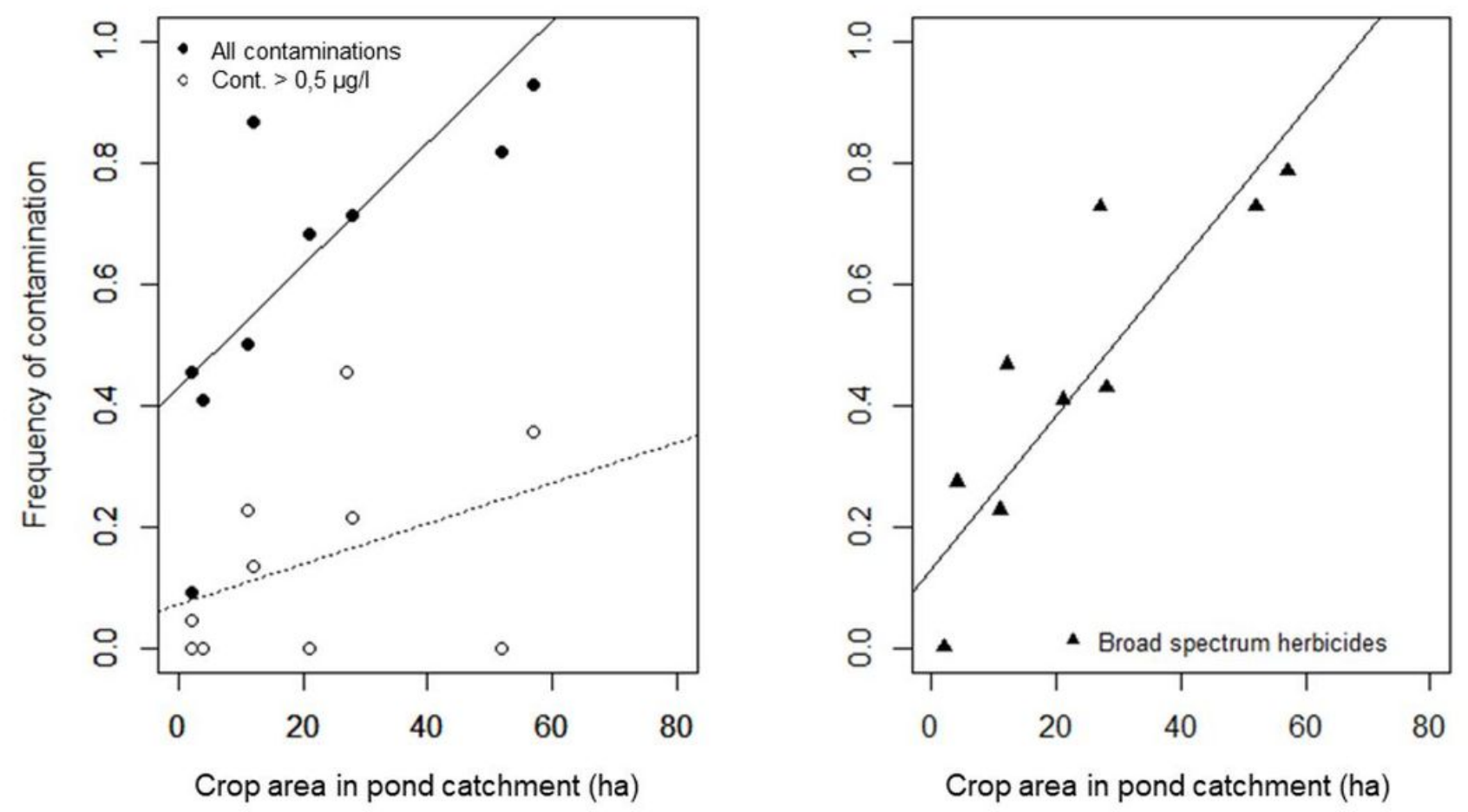

Figure 6

Effect of crop area in the catchment on the frequency of contamination of 10 fish ponds with pesticides residues: for all contaminations, all contaminations $>0,5 \mu \mathrm{g} / \mathrm{l}$ and only broad spectrum herbicides residues contaminations (principally glyphosate or AMPA) for three years' water sampling of the Dombes area, France. The results of linear modelling are respectively: all

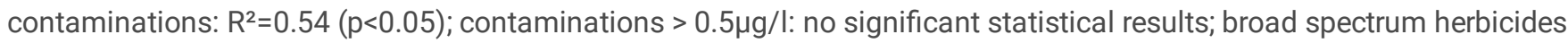
contaminations: $\mathrm{R}^{2}=0.77(\mathrm{p}<0.001)$.

Figure 7

Summed annual crop areas (left) and variation of winter cereals and maize areas (right) in the 10 fish pond catchments over the three years of pesticides monitoring. 